IRSH 50 (2005), Supplement, pp. 43-63 DOI: I0.10I7/So020859005002063

(C) 2005 Internationaal Instituut voor Sociale Geschiedenis

\title{
Deciding Whom to Marry in a Rural Two-Class Society: Social Homogamy and Constraints in the Marriage Market in Rendalen, Norway, I750- I900*
}

\author{
HANS HENRIK B ULL
}

Summary: This article presents the findings of a long-term study of social homogamy in the rural community of Rendalen, Norway, in the eighteenth and nineteenth centuries. Prior to 1870 , the occupation of parents was not normally recorded in the Norwegian parish registers. It is therefore difficult to carry out historical studies of social homogamy in Norway over any length of time. The Rendalen database, however, provides this information from several other sources. Structural changes over time, which led to an increase in the number of farm workers, reduced the degree of homogamy among farmers as well as creating a larger marriage market for the farm workers, thereby increasing homogamy among these farm workers. Controlling for these structural changes, it is clear that social boundaries between farmers and farm workers prevailed at least until the end of the nineteenth century. Using a multivariate analysis, we are able to identify different family characteristics that led young men and woman to marry homogamously. The farmers, especially, exerted influence on their eldest sons to marry farmers' daughters, but the role of the father in the mating process also secured more economically viable partners for the other children too.

\section{INTRODUCTION}

In preindustrial rural society, a marriage did not involve simply forming a personal union; it also marked the start of a production unit. The choice of partner could have a great effect on economic outcome later in life. In this context, marriages could not be based solely on personal affection. This article presents the findings of a long-term study of social homogamy in the rural community of Rendalen, Norway, in the eighteenth and nineteenth centuries. It examines in what way social boundaries between the classes constrained the choice of marriage partner, and whether the role

\footnotetext{
This article is part of my doctoral thesis. I am grateful to the Research Council of Norway for financial support. I am also grateful to the editorial committee of this journal for helpful comments and suggestions, and to Sølvi Sogner, Nico Keilman, George Alter, Mona Renate Ringvej, Svenn-Erik Mamelund, and Jennifer Høibråten.
} 
of parents influenced their children's decision on whom to marry. Information is gathered and analysed using a population database based on family reconstitution methods. This makes it possible to identify the father's social position, information which is not obtainable directly from Norwegian marriage records.

\section{B A C K GROUND}

In modern sociological research marriage patterns are regarded as the result of an interplay between three social forces: the preferences of the individual for a specific marriage candidate, influences from a person's own social group, and structural constraints in the marriage market. ${ }^{I}$ An important structural constraint that can affect the degree of social homogamy is the relative number of individuals within each social group. The degree of homogamy is likely to be lower in a heterogeneous population. Especially within small social groups, the chance of marrying homogamously is relatively limited. Changes in the composition of these social groups can be controlled for to get a clearer view of the sort of boundaries that existed between classes.

Such boundaries between social groups in the marriage market could be enforced by third parties. In the Scandinavian peasant community parents are seen as influencing their children's marriage choices. It has been claimed that the degree of parental control was one effect of social stratification. The Swedish ethnologist, Orvar Löfgren, has emphasized that the large landless population that existed in the nineteenth century in the province of Scania in southern Sweden was an important explanation for the rigorous premarital parental supervision that was prevalent among farmers in the area. ${ }^{2}$ Parents who feared that their children would marry downward went to great pains to organize a suitable marriage. The children were rather passive in this process. Löfgren states that the "parental control and strategic matchmaking functioned as important instruments for consolidating the social and economic position of well-todo peasant families". ${ }^{3}$

The matchmaking process was quite different in the region of Dalecarlia in mid-western Sweden. Here, in a more egalitarian society dominated by smallholders, parental control was less prevalent. Young people played a

I. Matthijs Kalmijn, "Intermarriage and Homogamy: Causes, Patterns, Trends", Annual Review of Sociology, 24 (1998), pp. 395-42 I, 398 ff.

2. Orvar Löfgren, "Family and Household among Scandinavian Peasants", Ethnologia Scandinavia, 2 (1974), pp. 17-52, 30 ff. See also Martin Dribe and Christer Lundh, "Finding the Right Partner: Rural Homogamy in Nineteenth-Century Sweden”, pp. I49-177 in this volume, for a discussion of homogamy in Scania.

3. Löfgren, "Family and Household among Scandinavian Peasants", pp. $30 \mathrm{ff}$. 
more active part in searching for partners, in the form of so-called "nightcourting". This was one way in which they could meet together in the sleeping quarters of young women on Saturday night, where they could develop and test their attraction to one another; eventually, this could lead to marriage. Löfgren explains this freedom from parental control in terms of parents being less afraid that their children would marry downward.

The institution of night-courting as part of the mating process was also of great interest to Eilert Sundt, the Norwegian pioneer of sociology and social anthropology, who studied the marriage patterns of the landed population in the i 850 s. In the period I 848 to I 869 Sundt received several grants from the Norwegian government to study social conditions in Norway following the unrest among farm workers at the time. During these years he published a series of treatises covering such topics as mortality, marriage, sexual morality, cleanliness, temperance, domestic life, and the gypsies in Norway. He used a combination of quantitative and qualitative analysis, based on research methods such as questionnaires and interviews. ${ }^{4}$

Sundt explained night-courting as a way in which young people were able to get to know each other while at the same time allowing parents some control over the mating process.' Even though the courting happened in secret, parents had some idea about what was going on, and could give hints as to whether they approved of the connection or not. But Sundt also noted that this process made it more difficult for the parents seriously to disapprove of the marriage when the suitor announced himself. And as social stratification increased, the stakes became higher. In the Hedemarken region in the southeast of Norway, Sundt found that during the period of rural proletarianization in the mid-nineteenth century the traditional night-courting started to break down among affluent farmers. Instead of allowing night-courting, parents arranged small parties for their children where they could meet boys and girls from other farms in the area. ${ }^{6}$ In this way, the meetings between young people could be more effectively controlled by the parents, and excessive socialization with social groups of lower status could be averted. Controlling the social networks of their children, the parents also managed to strengthen the group identification of their children and sustain firm social boundaries.

The idea of ever-increasing constraints on intersocial marriages during rural proletarianization in the nineteenth century is somewhat contrary to

4. Michael Drake, "Introduction", in Eilert Sundt, On Marriage in Norway, tr. and introduced by Michael Drake (Cambridge, I980), p. xiv.

5. Eilert Sundt, Sexual Customs in Rural Norway: A Nineteenth Century Study, tr. Odin W. Anderson (Ames, IA, I993), pp. $53 \mathrm{ff}$.

6. Sundt, On Marriage in Norway, pp. 164 ff., n.I4; Sundt, Sexual Customs in Rural Norway, p. 66; Löfgren, "Family and Household among Scandinavian Peasants", pp. 3 off. 
the changes in family life that Shorter and Stone claimed took place from the end of the eighteenth century. They argued that the selection of marriage partner was increasingly based on romantic love, with an ensuing reduction in parental authority and collective control.7 Shorter and Stone's general theories have been much debated. While Macfarlane has stressed the importance of romantic love as a significant factor in matchmaking as early as the sixteenth century, others have claimed that great regional diversity persisted even within countries. ${ }^{8}$ In the Norwegian context Kari Telste has argued, on the basis of court records, that there was a shift around I 800 whereby young people, influenced by the ideal of romantic love, demanded from their parents greater freedom to follow their own feelings. However, until the end of the nineteenth century parents could still exercise substantial influence on the marriage choices of their children. ${ }^{9}$

Perhaps the introduction of the ideal of romantic love led parents to control the mating process even more firmly. If children risked losing their way in the process of night-courting, falling in love with the wrong person, parents would take action to prevent this from happening. The idea that love was something of a mishap in the mating process among the rural population is also consistent with Sundt's impression at the time. He asserts that while romantic love flourished in the towns, the peasant youth searched for a partner in ways that can best be characterized as "looking for a marriage of convenience".

This was the case for the children of both the landowning and the landless population. According to Sundt, the sons of farmers sought a girl with an inheritance or a dowry that would help pay for a farm. In a time of extensive rural proletarianization, the sons of landowning farmers avoided choosing marriage partners who would cause them to experience downward social mobility. ${ }^{\circ}{ }^{\circ}$ In the quest for economic security, children did not necessarily resent parental control in the matchmaking process, as Löfgren has pointed out. At a time when a good farm was the main prerequisite for economic security and social prestige, parental counsel in the choice of marriage partner was often welcomed. ${ }^{\text {I }}$

Likewise the son of a cottar or worker would not even aspire to marry the daughter of a farmer, seeking instead a capable working mate with solid experiences as a farm servant. Sundt stressed that children from the lower

7. Edward Shorter, The Making of the Modern Family (London, 1976), and Lawrence Stone, The Family, Sex and Marriage in England I 500-I800 (New York, I977).

8. Alan Macfarlane, Marriage and Love in England: Modes of Reproduction, 1300-1840 (Oxford, 1986). Martine Segalen, Love and Power in the Peasant Family: Rural France in the Nineteenth Century (Oxford, 1983).

9. Kari Telste, "Familien som kjenslefellesskap", in Sølvi Sogner (ed.), I gode og vonde dagar.

Familieliv $i$ Noreg frå reformasjonen til vår tid (Oslo, 2003), pp. I I9-196, I34 ff.

Io. Sundt, On Marriage in Norway, pp. I 53 ff.

I I. Löfgren, "Family and Household among Scandinavian Peasants", p. 3 I. 
rural classes could not afford anything else because they recognized that it was the labour of the man himself and his wife that supported them. ${ }^{\mathrm{I}}{ }^{2}$ Sundt emphasized that, among the rural classes, a potential partner's economic attributes took precedence over his or her cultural resources, even when individuals were free to choose independently. Basing the decision on whom to marry on romantic love was a freedom limited to the urban population. Here an educated young man who had built up an independent position was at greater liberty to consider "personal charm and attractiveness" when choosing his bride. ${ }^{13} \mathrm{He}$ had the economic freedom to choose a wife based on personal affection.

\section{STUDYING SOCIAL HOMOGAMY IN NORWAY}

Prior to I870, the occupation of parents was not normally recorded in Norwegian parish registers. It is difficult therefore to carry out historical studies of social homogamy in Norway over any length of time. In addition, the strict privacy-protection law limits more extended research based on digitized sources after I900. The few studies carried out have used data from family reconstitutions or other kinds of linked datasets. Using data from these kinds of sources, Dag Kristoffersen found that there were few mixed marriages between social groups, in his case between farmers and miners in the parish of Sandsvær in the eighteenth century. ${ }^{14}$ The studies by Alf Steinar Kneppen and Ståle Dyrvik on social mobility in rural communities confirm this impression. They found that very few farm wives came from the cottar class, while Dyrvik's study also indicated that many cottar wives were the daughters of farmers. This is explained by the downward social mobility they experienced following their marriage to the younger sons of farmers, who were obliged to settle on a small cottar farm when the eldest brother took over the family farm. ${ }^{15}$

In a study of social mobility in the city of Bergen at the end of the nineteenth century, Yngve Torvanger demonstrated that women had a higher degree of upward mobility in marriage than men. He also showed that, even though intergenerational mobility for men declined over time, the possibility of upward mobility through marriage gradually increased. ${ }^{16}$

I2. Sundt, On Marriage in Norway, p. I57.

13. Ibid., p. I55.

I4. Dag Kristoffersen, “'To bønder på en bergmann.' Befolkningsutviklingen i Sandsvær 1750I 801 " (unpublished dissertation, University of Oslo, I983), pp. $254 \mathrm{ff}$.

I 5. Alf Steinar Kneppen, "Giftermål og sosiale ulikheter i Ullensaker fra I730-åra til i 840-åra" (unpublished dissertation, University of Oslo, 1976), p. 26; Ståle Dyrvik, "Om giftarmål og sosiale normer. Ein studie av Etne I7 I 5-I80 I”, Artikler i etnologi, Institutt for etnologi (Oslo, 1987), pp. 27-4I, 36.

I6. Yngve Torvanger, "Sosial mobilitet i Bergen i 850-1900: en kohortundersøkelse for rode 23 og 24" (unpublished dissertation, University of Bergen, 2000). 


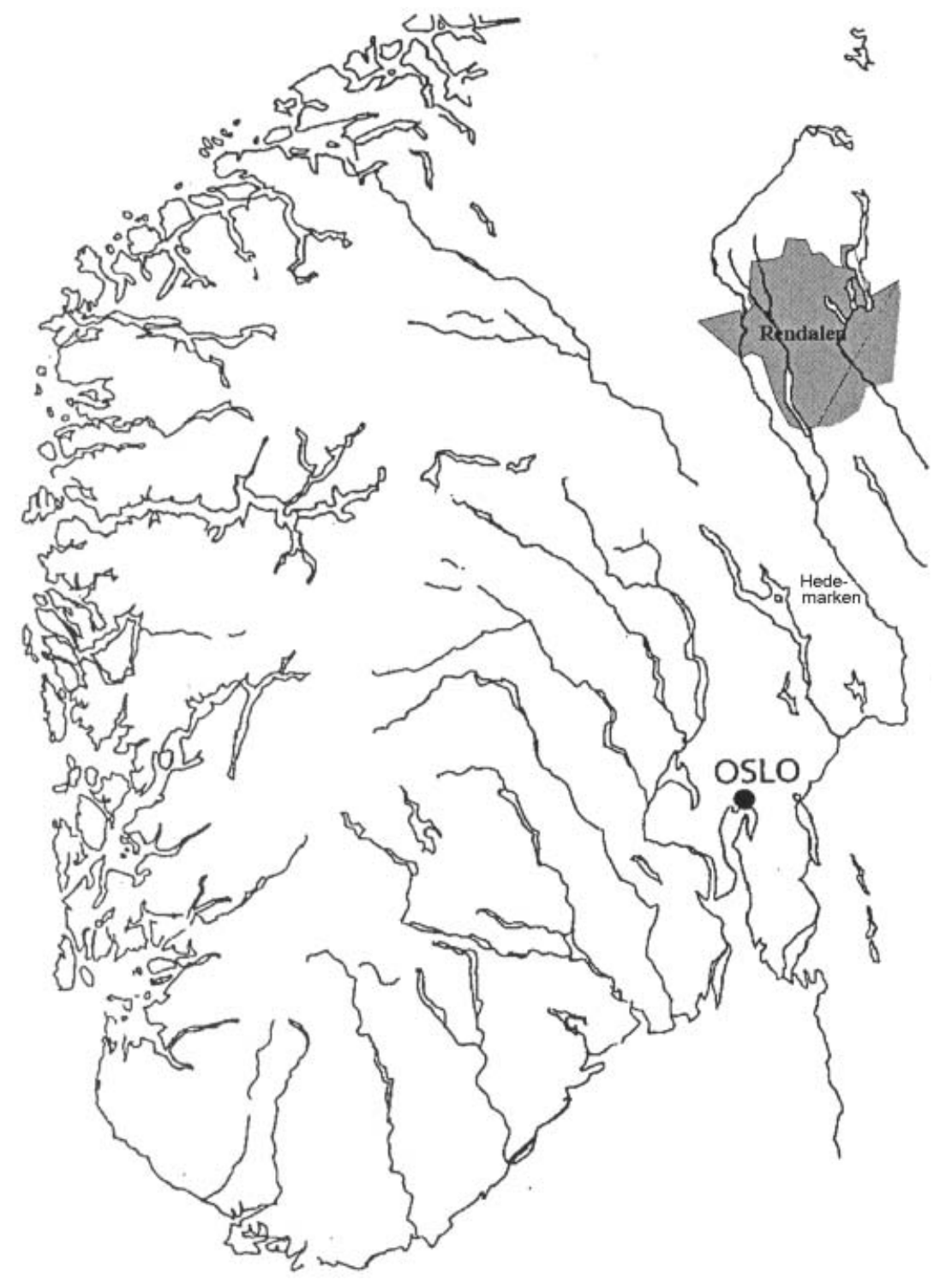

Figure I. The parish of Rendalen in Norway.

Torvanger's findings point towards an increasingly more open urban society that was becoming less constrained by social boundaries. However, so far there has been no study of social homogamy covering a time span sufficiently long to verify and support Sundt's findings, I 50 years ago, of a division between urban and rural areas concerning personal preferences in the choice of marriage partner. 


\section{AREA OF STUDY}

Throughout the period covered in this study, Rendalen was an overwhelmingly rural area with a limited degree of occupational opportunities. This somewhat reflects the reality of Norway, where industrialization developed fairly slowly in the nineteenth century; only I 6 per cent of the population lived in urban areas in 1865 . Using the HISCLASS classification, ${ }^{17}$ one sees that Rendalen was a two-class society of farmers (8) and farm workers (IO+I2). More than 95 per cent of those marrying were children of farmers or farm workers (Table I, overleaf). Even at the end of the nineteenth century, less than Io per cent came from a social group outside the farming community. Our analysis and discussion of homogamy will therefore revolve around the division between farmers and farm workers.

The farmers in Rendalen were mostly freeholders, who settled on a separate farmstead. Their production was largely organized as a subsistence economy based on agriculture and animal husbandry. By the middle of the nineteenth century, better access to cheap grain shifted farm production towards meat and dairy products for sale. This process was also supported by an upsurge in lumber prices, which created large incomes, especially for those farmers with forest property.

The group of farm workers was a relatively new social group in the eighteenth century. By the middle of the nineteenth century Norwegian peasant society had evolved from a relatively egalitarian peasant community to a more stratified society dominated by freeholders and cottars. The number of cottars rose substantially in the eighteenth and nineteenth centuries due to population growth and a relatively limited number of new farms. In reality, the cottages were small farmsteads, but formally they were integrated into the farm to which they belonged. The cottar was the farmer's tenant and had to pay him rent either in labour or in cash. The farmer could also request at any time the labour of the cottar or his wife at a fixed price. ${ }^{18}$ The cottar institution ensured a stable and reliable workforce for the large farms. In the middle of the nineteenth century, the rise in the number of cottars abated and instead the group of day labourers expanded. The latter often rented sleeping quarters and worked on farms during the summer and as lumberjacks in wintertime. In this study, using HISCLASS, cottars and day labourers are taken as one social group (farm workers).

17. M.H.D. van Leeuwen and I. Maas, "HISCLASS", paper presented at the sth European Social Science History Conference (Berlin, 24-27 March 2004), and I. Maas and M.H.D. van Leeuwen, "SPSS Recode job from HISCO into HISCLASS", May 2004.

I 8. Sølvi Sogner, "Freeholder and Cottar: Property Relationships and the Social Structure in the Peasant Community in Norway during the Eighteenth Century", Scandinavian Journal of History, I (1976), pp. I8I-I99, I8 I ff. 


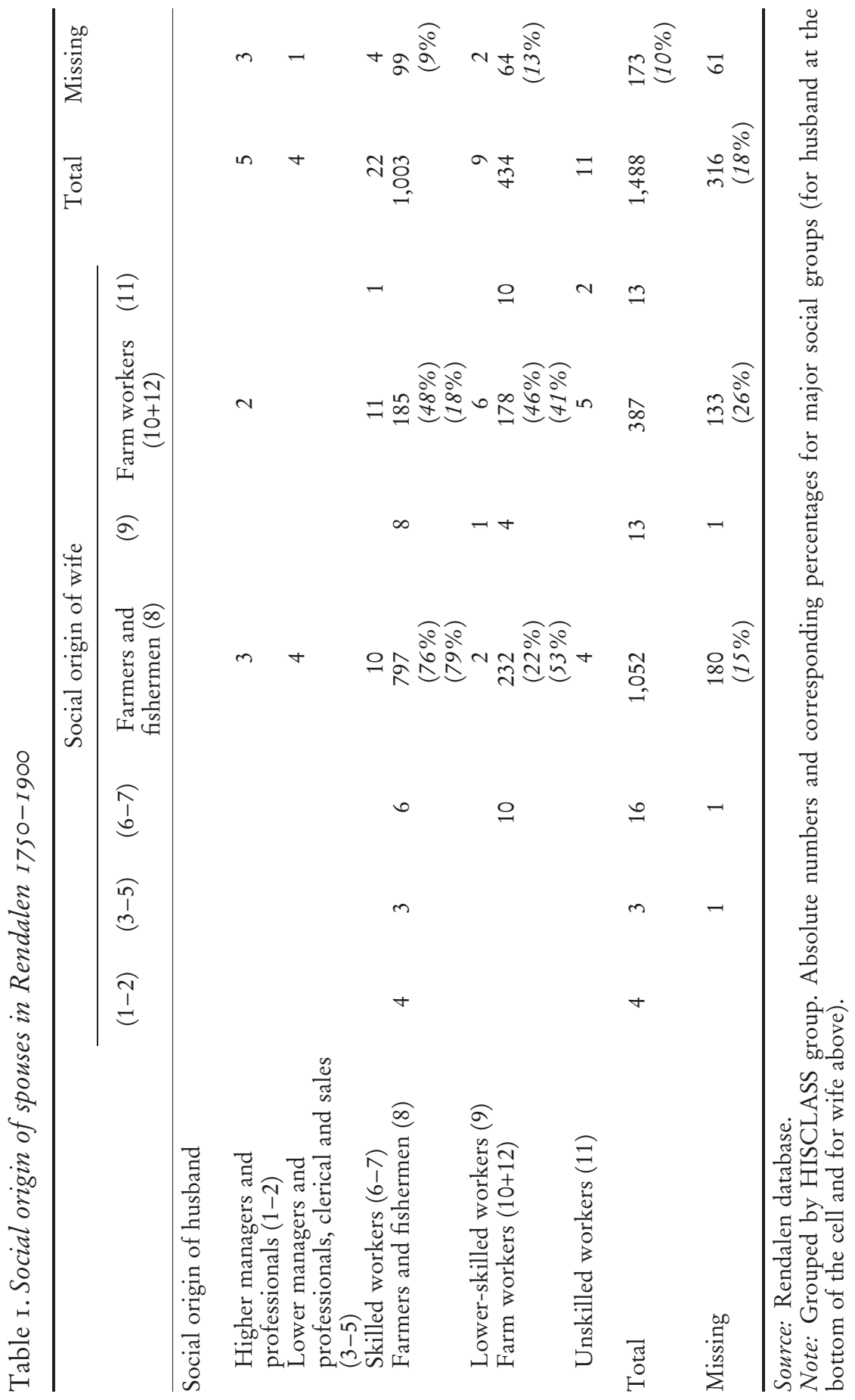




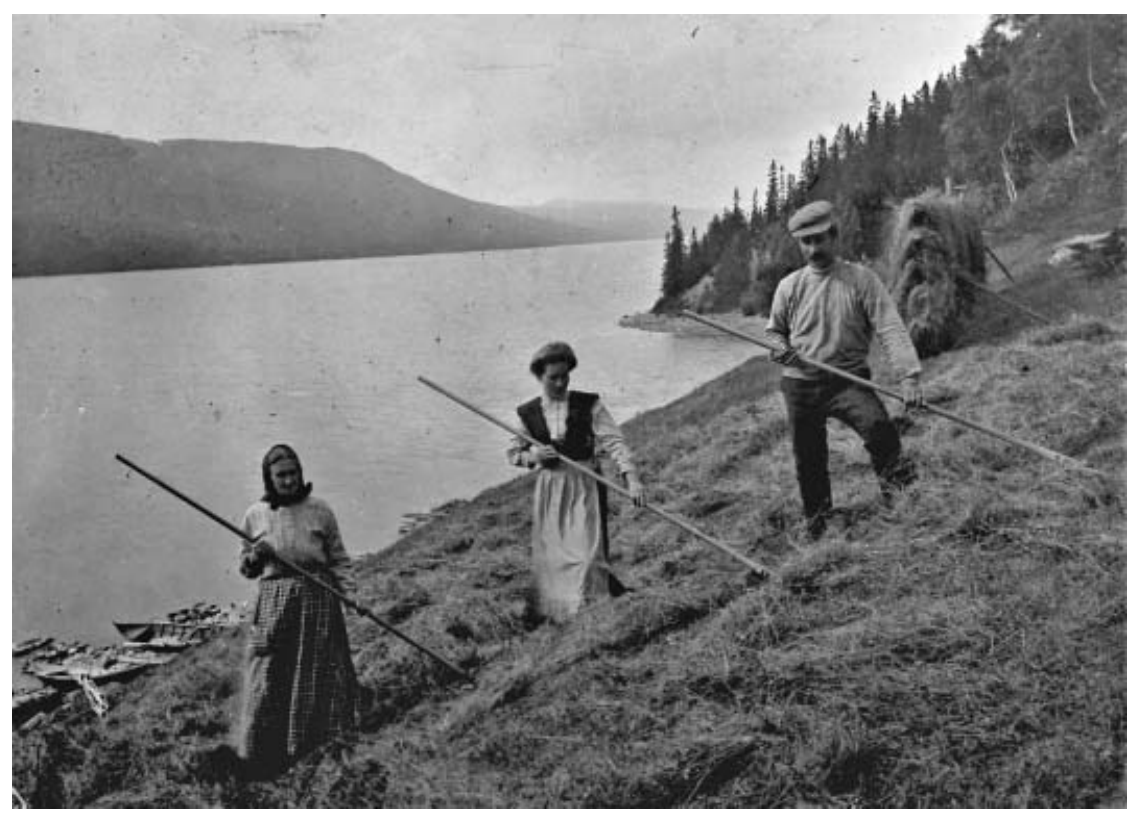

Figure 2. Farm workers on a small farm in Rendalen, c. 1900.

The work performed by farmers and farm workers was not particularly different. The farmer worked alongside his hired workers, and in the parish of Rendalen - unlike the Hedemarken region mentioned earlier - they would all eat together. They were all part of the same peasant culture. But the farm workers were subordinated to the farmers. The farmer was the manager both in his field and in his forest, while his wife supervised the work of female farm workers hired to help with domestic tasks. The wealth of a farm gave it an independent position in the community, and also determined its official position in the local community. This was especially the case after the I8I4 constitution, when wealth became a prerequisite for the right to vote. As to night-courting, the practice seems to have persisted during the whole period despite fierce opposition from the local clergy. ${ }^{19}$

\section{A T A}

This article draws on the Rendalen database to study homogamy and the choice of marriage partners in the parish of Rendalen. The database covers 
about 2,200 marriages contracted in the parish over the period I734-I900, and is linked by family reconstitution to birth and death records. ${ }^{20}$ This makes it possible to trace the parents of the persons marrying. Several other sources, such as censuses, farm registers, and court journals, make it possible to determine the socio-economic position of the fathers close to the time of marriage. In cases where the father had died before the marriage, we used either his social position at the time of death or the position stated in the source closest to the time of death.

Because of the difficulty in identifying the family of origin in the earliest years, this study examines only those marriages that took place after 1750 . Another problem which leads to the exclusion of certain marriages from the analysis is the difficulty in identifying the social status of fathers from other parishes. Fortunately for this analysis, Rendalen had a fairly stable population, and in 65 per cent of the marriages the families of both the wives and husbands were from Rendalen (Table 2). By studying the parents' occupations stated in the marriage register after I 874 and the data available from the national digitized censuses of I80I, I865, and I $875,{ }^{21}$ it has proved possible to identify some of the parents of in-migrants to the community and their occupations. Excluding from our study those marriages where the social status of either the man or the woman is not recorded leaves just under I, 500 marriages on which to base our analysis.

Most of the marriages excluded from the study are those of women marrying men from other parishes where the social status of the fathers is unavailable. The seemingly higher propensity for girls to marry someone from another parish is the result of two phenomena. One is the longstanding custom of marriages taking place at the church attended by the wife-to-be. Therefore, if the groom came from a parish outside Rendalen and the bride from Rendalen itself the marriage would still only appear in the marriage records in Rendalen - even if the couple were to settle in the groom's parish. Because of this, there is a corresponding "hidden" exclusion of men from Rendalen marrying girls from a neighbouring parish. Parish birth records document the birth of a legitimate child to a couple, from which the assumption may be made that a wedding has taken place somewhere else. If the cross-parish marriages were to be included, the number of marriage partners of unknown social status would be the same for sons and daughters of farmers. Still, the marriage of a Rendalen girl to a groom of unknown social

20. A comprehensive description of the database is currently obtainable only in Norwegian. See Martha Cecilie Gjelseth, "Relasjonsdatabaser som verktøy i en historisk-demografisk studie" (unpublished dissertation, University of Oslo, 2000).

21. The censuses of I80I, I865, and I875 were made available by the Digital Archives at www.digitalarkivet.no; the censuses of 1865 and 1875 are also available from the Norwegian Historical Data Centre at www.rhd.uit.no. The digitized census of I 875 covers only part of the country. 
Table 2. Geographic origin and knowledge of fathers' social status for couples marrying in Rendalen, 1750-1900

\begin{tabular}{lccccc}
\hline & \multicolumn{2}{c}{ Family from Rendalen } & & \multicolumn{2}{c}{ Social status known } \\
\cline { 2 - 3 } \cline { 5 - 6 } & Number & Per cent & & Number & Per cent \\
\hline Both & 1,322 & 65 & & 1,488 & 73 \\
Only wife & 424 & 21 & & 316 & 16 \\
Only husband & 200 & 10 & & 173 & 8 \\
Neither & 92 & 5 & & 61 & 3 \\
\hline Total & 2,038 & 100 & & 2,038 & 100 \\
\hline
\end{tabular}

Source: Rendalen database.

status occurred to a much higher degree among the daughters of farm workers (26 per cent; see Table I, p. 50). This is the result of another phenomenon: the migration of men seeking employment in the expanding forestry industry in the nineteenth century. These would normally marry girls from the lower social class. In this way the daughters of farm workers found a larger number of possible marriage candidates within Rendalen.

\section{HOMOGAMY AMONG FARMERS AND FARM WORKERS}

Table I shows a clearly higher degree of homogamy among farmers than among farm workers. The percentage given in italics in certain cells refers to the proportion of brides from the given social class where the social origin of the groom is known. The corresponding percentage for grooms appears at the bottom of the cells. It may be seen that of the sons of farm workers, 53 per cent married farmers' daughters, while only 22 per cent of farmers' daughters married sons of farm workers. Actually, both sons and daughters of farm workers married children of farmers more often than they married a member of their own social class ( 53 per cent for men and 48 per cent for women). Over time, homogamy among children of farmers declined. In the marriages that took place in the years between I 840 and 1900, 73 per cent of men and 64 per cent of women married homogamously, compared with 86 per cent and 80 per cent respectively in the period before.

Children of farm workers experienced the opposite development. Here, the degree of homogamy rose from 27 per cent to 48 per cent, and from 35 per cent to 50 per cent for men and women respectively. In the middle of the eighteenth century up to 90 per cent of all those marrying were children of farmers. This was due in part to a larger proportion of farmers, but also to the fact that farmers usually had more children than cottars and workers. With the extensive population increase, combined with the 
limited number of new farms, proletarianization led to a rise in the number of cottars and workers. This process was in large part due to the downward social mobility experienced by the children of farmers. At the end of the nineteenth century 40 per cent of those marrying were children of farm workers. This structural development in the relative numbers of possible marriage partners from the two social groups may explain changes in the degree of homogamy over time.

One way to control for these structural changes is to calculate the odds ratio. The odds ratio is defined as the odds of, for example, the son of a farmer marrying the daughter of a farmer, divided by the odds of a man of other social origin (all other social groups) marrying the daughter of a farmer. Odds ratios are therefore independent of the relative size of the social groups. ${ }^{22}$ The odds ratios in Figure 3 show an unstable pattern of homogamy in the eighteenth century, a pattern which is mostly explained by the low numbers of farm workers marrying. However, more importantly, it indicates a fairly stable pattern during the nineteenth century among both social groups. Consequently, at the end of the nineteenth century there is little evidence for a more open society when it comes to social homogamy.

For the group of farmers as a whole, there was a consolidating trend at the end of the nineteenth century towards marrying within one's own class. This is consistent with the idea of Löfgren and Sundt that a larger working class and a clearer stratification between the classes strengthened social homogamy. In Rendalen, where the social landscape consisted primarily of only two classes, the closeness among the group of farmers also limited the number of marriage candidates for the lower class. This may be seen in the increase in homogamy among farm workers at the end of the period. The paucity of possible marriage partners and work opportunities not only led children of farm workers to seek marriage candidates from other parishes, but also to leave Rendalen before marriage more often than the offspring of farmers (33 per cent compared with 20 per cent). For the young people who chose to marry and stay in Rendalen, the social boundaries that separated farmers from farm workers were definitely still in place in 1900 .

\section{DECIDING WHOM TO MARRY}

It has been shown that social homogamy prevailed in Rendalen during the nineteenth century, but does the study of homogamy say anything about the decision about whom to marry? More exactly, does it indicate anything

22. Kalmijn, "Intermarriage and Homogamy", p. 405. 


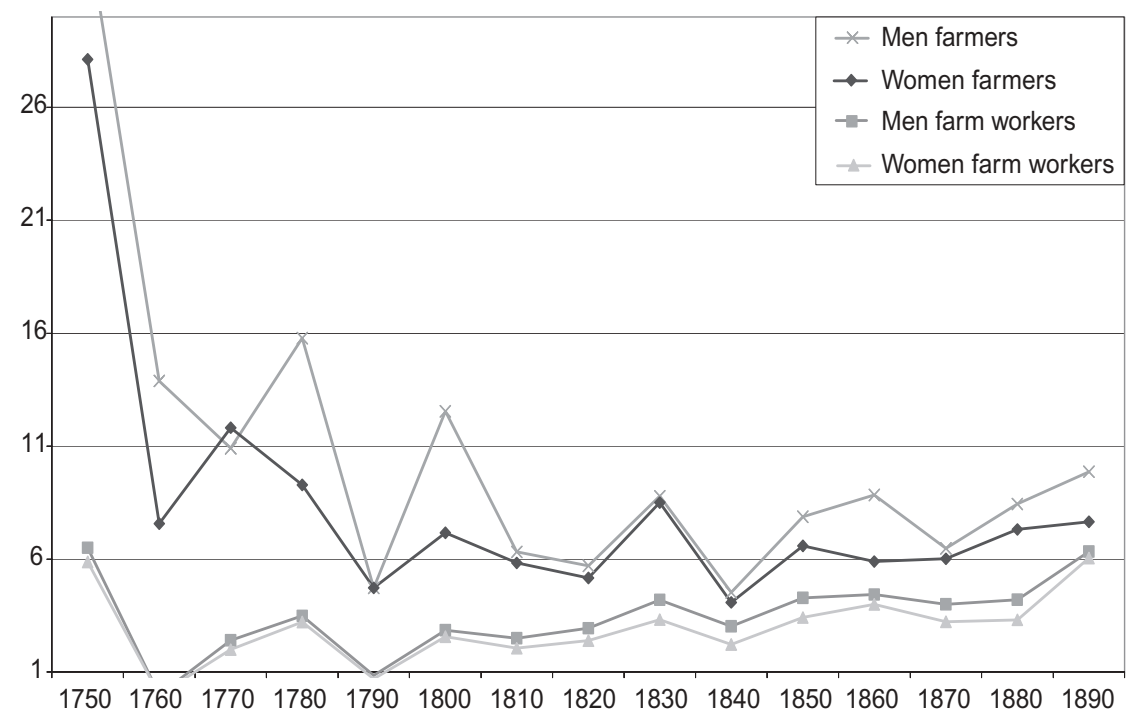

Figure 3. Odds ratio of marrying homogamously among children of farmers and farm workers, Rendalen, I0-year periods, 1750-1900.

about individual preferences versus parental control in spouse selection within these structural conditions?

An analysis of spouse selection between brothers within the sibling group gives some insight into the considerations governing the selection of marriage partner. Rendalen has been characterized as a stem family society. The freeholder inheritance law (asetesretten) stipulated that the eldest son had the right to succeed his parents as head of the farm. In Rendalen the two generations would live together and share a common household after the marriage of the eldest son. Parents would therefore be more inclined to control the heir's choice of spouse than that of the younger sons. ${ }^{23}$ If parental influence played an important role in the decision of the eldest son to marry homogamously, a difference might be seen between the eldest son and his younger brothers. The unique position of the farmer's eldest son is reflected in the way he married at a clearly lower age than his younger brothers. ${ }^{24}$

The fathers of almost half of the men marrying for the first time were no longer alive at the time of the wedding. The death of a father could affect the degree of homogamous marriage in two ways. The economic capital and social position of the family could be reduced if the father died early. 
Frans van Poppel et al. found that the death of a father, particularly before the sons had reached the age of fifteen, had a negative effect on their opportunities in the marriage market. ${ }^{25}$ Another possibility is that the death of a father enabled the children to choose their partners more freely, enabling some of them to find partners outside their own social group. Our study tries to separate these two effects and determine whether the father's death had any impact on his sons' choice of marriage partner.

The results of logistic regressions of marrying homogamously for the children of farmers in Rendalen in the years 1750-1900 are presented in Tables 3 and 4. Only first marriages for the sex in question are included. The analysis is also limited to families from Rendalen in order to determine the position (youngest or eldest for example) within the group of siblings and the presence of parents. The same analysis was also performed for the children of farm workers, but, since this gave no significant results other than for the time periods, it is not included here. In the models we are controlling for time and the changing proportion of brides (Table 3), and grooms (Table 4) belonging to the group of farmers. Apart from these variables, which indicate changes in the relative size of the social groups over time, all the explanatory variables used are binary (dummy) variables. The averages of the explanatory variables are presented in the first column. The second column gives the coefficient estimate of the variables, where the reference variable is null and the values give a positive or negative effect compared with this variable. The third column gives the $\mathrm{t}$-statistics, and the statistically significant values (two-tailed test) at the ro-per-cent level are marked in bold.

The models for sons of farmers are discussed first. Model I shows a clearly negative effect on marrying homogamously of fathers dying when the sons are still young. This indicates a negative economic development before the time of marriage which affected the young man's position in the marriage market. Statistical tests were also conducted to discover whether it was the widow's new husband which had the effect of reducing the opportunities for her sons from her first marriage. It appears that this had no effect, and hence the results are not shown here.

Surprisingly, there is no difference between the eldest son and his younger brothers in model I. At first glance it seems that fathers did not influence the choice of marriage of their eldest sons in a way that made them marry more homogamously. But model 2 includes an interaction of the eldest son marrying after the father had died while the son was fairly old. This clearly lowered the propensity to marry homogamously, suggesting that the father did put pressure on the eldest son to marry homogamously (the main effect is strengthened). Since the death of the 
Table 3. Logistic regression coefficients of marrying homogamously for sons of farmers: men marrying for the first time, 1750-1900

\begin{tabular}{|c|c|c|c|c|c|}
\hline & \multirow[b]{2}{*}{ Mean } & \multicolumn{2}{|c|}{ Model 1} & \multicolumn{2}{|c|}{ Model 2} \\
\hline & & Value & t-value & Value & t-value \\
\hline (Intercept) & & 1.44 & 5.99 & -1.23 & -0.92 \\
\hline Marrying a widow & $(0.06)$ & 0.72 & 1.55 & 0.71 & 1.52 \\
\hline $\begin{array}{l}\text { Position in group of siblings (ref. } \\
\text { second oldest) }\end{array}$ & $(0.26)$ & & & & \\
\hline Eldest brother & $(0.43)$ & 0.12 & 0.56 & 0.33 & 1.31 \\
\hline Younger brothers & $(0.29)$ & 0.14 & 0.60 & 0.12 & 0.50 \\
\hline Parents unmarried & $(0.02)$ & -0.07 & -0.12 & -0.02 & -0.05 \\
\hline Age at marriage (ref. 25-34) & $(0.58)$ & & & & \\
\hline Under 25 & $(0.18)$ & 0.22 & 0.82 & 0.22 & 0.82 \\
\hline Over 34 & $(0.24)$ & -0.50 & -2.34 & -0.52 & -2.41 \\
\hline \multicolumn{6}{|l|}{ Parents' position } \\
\hline Father dead before age 15 & $(0.15)$ & -0.62 & -2.35 & -0.58 & -2.16 \\
\hline Father dead after age 15 & $(0.30)$ & -0.27 & -1.26 & 0.01 & 0.03 \\
\hline Mother dead & $(0.29)$ & -0.20 & -1.02 & -0.19 & 0.00 \\
\hline \multicolumn{6}{|l|}{ Time period (ref. 1790-1830) } \\
\hline $1750-1790$ & $(0.22)$ & 0.74 & 1.82 & 0.72 & 1.78 \\
\hline $1830-1870$ & $(0.28)$ & 0.40 & 1.27 & 0.44 & 1.37 \\
\hline $1870-1900$ & $(0.26)$ & 0.47 & 1.14 & 0.50 & 1.22 \\
\hline $\begin{array}{l}\text { Percentage daughters of farmers } \\
\text { marrying }\end{array}$ & $(0.70)$ & 3.52 & 2.04 & 3.59 & 2.07 \\
\hline $\begin{array}{l}\text { Eldest brother * Father dead after age } \\
15\end{array}$ & $(0.10)$ & & & -0.69 & -1.75 \\
\hline$-2 \log \mathrm{L}$ & & \multicolumn{2}{|c|}{2582.1} & \multicolumn{2}{|c|}{2592.6} \\
\hline 1-(Residual deviance/Null deviance) & & \multicolumn{2}{|c|}{0.060} & \multicolumn{2}{|c|}{0.063} \\
\hline $\mathrm{N}$ & & \multicolumn{2}{|c|}{860} & \multicolumn{2}{|c|}{860} \\
\hline Events & & \multicolumn{2}{|c|}{689} & \multicolumn{2}{|c|}{689} \\
\hline
\end{tabular}

Bold $=$ significant $\mathrm{p}<0$. I0.

Source: Rendalen database.

father late in life did not have a substantial effect on the younger sons marrying exogamously, it seems that they sought a farm girl more in response to their own preferences. While the eldest son already had a firm economic position as a farmer, a younger son was more inclined to choose a marriage partner with the economic resources to secure his position.

In theory, sons could not marry against their father's will as long as they were under the age of majority (twenty-five until I 869). Yet the results of our study do not show any higher degree of socially homogamous marriages before this age. One reason for this might be that the children were under their fathers' authority as long as they were living at home. In this way the death of the father could have more effect on sons' marriage choices. On the other hand, sons of farmers who had postponed marriage 
Table 4. Logistic regression coefficients of marrying homogamously for daughters of farmers: women marrying for the first time, 1750-1900

\begin{tabular}{lrrr}
\hline & Mean & Value & t-value \\
\hline (Intercept) & & -1.18 & -0.89 \\
Marrying a widower & $(0.07)$ & 0.23 & 0.71 \\
Position in group of siblings (ref. second oldest) & $(0.29)$ & & \\
Eldest sister & $(0.37)$ & 0.18 & 0.93 \\
Younger sisters & $(0.32)$ & 0.03 & 0.13 \\
Parents unmarried & $(0.02)$ & -0.23 & 0.33 \\
Age at marriage (ref. 23-32) & & & \\
Under 23 & $(0.26)$ & 0.41 & 2.00 \\
Over 32 & $(0.19)$ & -0.81 & -3.98 \\
Parents'position & & & \\
Father dead before age 15 & $(0.15)$ & -0.06 & -0.24 \\
Father dead after age 15 & $(0.21)$ & -0.16 & -0.77 \\
Mother dead & $(0.26)$ & -0.26 & -1.42 \\
Time period (ref. 1790-1830) & $(0.24)$ & & \\
1750-1790 & $(0.21)$ & 0.53 & 1.51 \\
1830-1870 & $(0.28)$ & 0.02 & 0.08 \\
1870-1900 & $(0.27)$ & 0.22 & 0.59 \\
Percentage sons of farmers marrying & $(0.68)$ & 3.41 & 1.88 \\
-2LogL & & 2953.6 & \\
1-(Residual deviance/null deviance) & & 0.070 & \\
N & & 966 & \\
Events & & 729 & \\
\hline Bold significant p & &
\end{tabular}

Bold = significant $\mathrm{p}<0 . \mathrm{IO}$.

Source: Rendalen database.

until their mid-thirties were less attractive marriage candidates for the daughters of farmers.

It has been claimed that in a male-dominated society, men represent the demand and women represent the supply in the marriage market. ${ }^{26}$ Men seek the partners with the most sought-after characteristics, and the most eligible marriage partners marry first, that is, at an early age. In a subsistence agricultural society, the attractive characteristic is thought to be wealth. Hence, the age effect for daughters in Table 4 can be interpreted as a selection effect whereby the wealthiest daughters marry first, most often the sons of farmers. The least eligible women on the other hand had to build their own economic basis, and because their impecuniousness made them less attractive to sons of farmers, they were more often obliged to settle with someone from a lower class.

However, the theory that attractiveness is predicated on wealth is disturbed by the lack of effect on the daughter's choice of marriage partner 


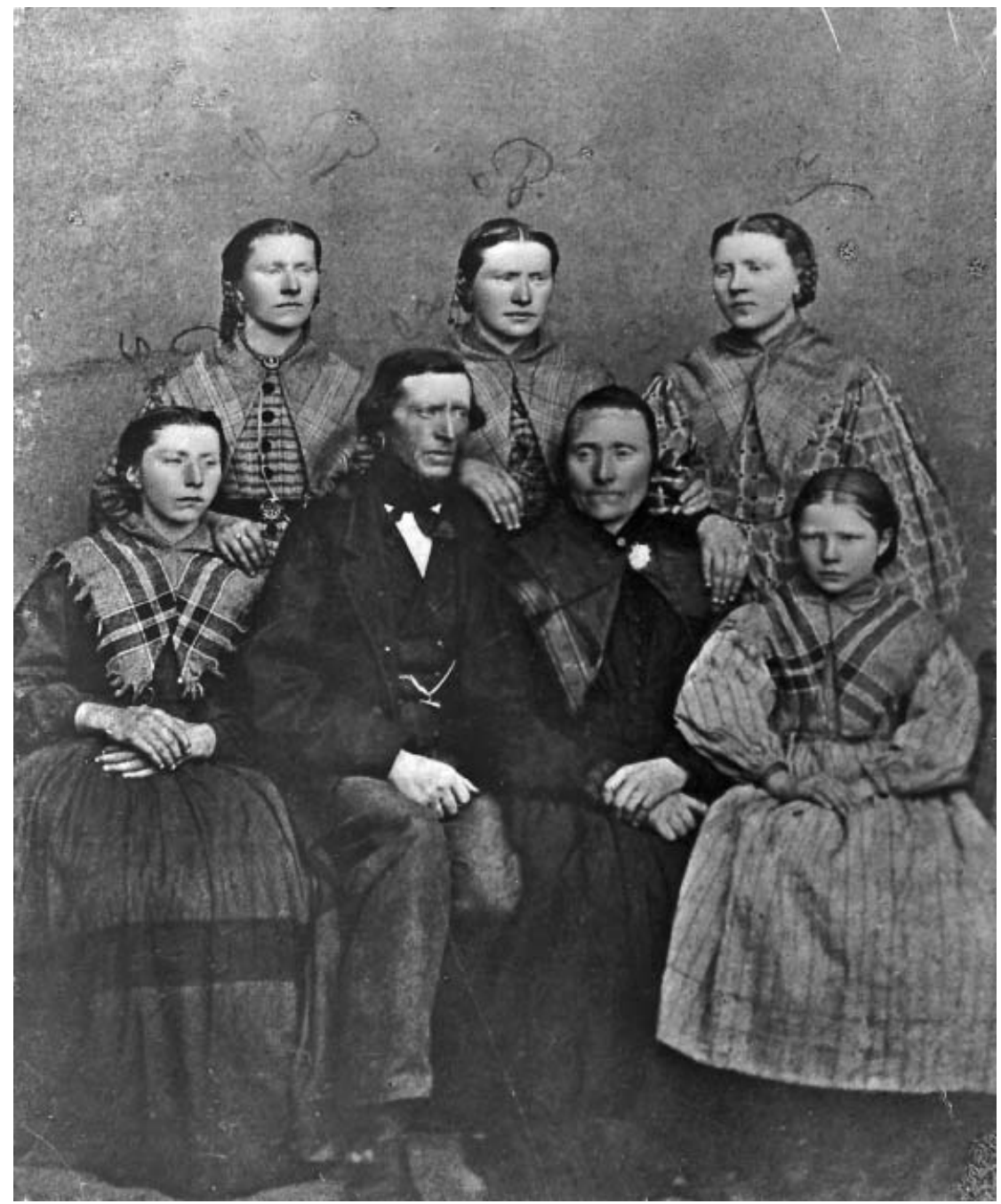

Figure 4. A farmer's family in Rendalen, c.I 870 ; four of the five daughters married sons of farmers.

Nordosterdalsmuseum, Tynset. Used with permission.

when the father died at an early age. For sons this was interpreted as a possible economic hardship in the time between the death of the father and the marriage. One possible explanation for the absence of this effect among daughters is that when the father had died, the daughters had more disposable wealth than they would otherwise have been entitled to through a dowry. This wealth would have been attractive to potential marriage partners. The probate registers from Rendalen show that the 
dowry could be quite small compared to the inheritance they later received.

\section{HOMOGAMY AND SOCIAL MOBILITY}

An analysis of the social mobility of men and women who married and settled in Rendalen sheds even more light on the importance of parents in making economically strategic partner choices. In Table 5 the results of a logistic regression of being a farmer as an adult are presented. Here, only those couples are included whose social status we know. Becoming a farmer is taken as the most attractive economic outcome in Rendalen, since other sources of income outside agriculture were limited during the whole period. A negative effect is taken as a sign of reaching a lower social position compared with being a farmer.

The social origin of both men and women is highly important when it comes to social mobility. When both the man and the woman were the children of farmers, the chance of their becoming farmers was greater. Of the 5 I 9 couples included in the study, 386 managed to maintain their social position as farmers. It was a different story for the children of farm workers marrying homogamously. Only 33 of 95 couples in this category rose in terms of social position ( 22 became farmers). Many of these were cottars who managed to buy their cottar farm and become freeholders. The results in Table 5 demonstrate how important it was for the children of farmers to group their economic resources. Marrying exogamously led to a higher propensity to downward mobility for the children of farmers. Here the eldest son of a farmer was in a unique position (as the interaction effect displays) since he was entitled to the family farm.

The results in Table 5 indicate that the death of the father before the marriage of his offspring affected the likelihood of that offspring's becoming a farmer as an adult. This was the case both for the bride and the groom. The effect of the father's death for men has already been picked up in the form of socially mixed marriages, but there was an additional effect on social mobility. Perhaps fathers had an important role in selecting economically viable partners for their children from within the group of farmers. This effect would have been lost when the father was no longer present. Without his influence, the choice of marriage partners that the children made on their own might not have been as economically successful.

\section{CONCLUSIONS}

The study of homogamy in Rendalen shows that, among farmers, social homogamy was declining in the nineteenth century. This was due to the rural proletarianization of the eighteenth and nineteenth centuries, which increased the size of the group of farm workers, thereby expanding the 
Table 5. Logistic regression coefficients of becoming a farmer after marriage: first marriages of men and women from Rendalen, 1750-1900

\begin{tabular}{|c|c|c|c|c|}
\hline & & Mean & Value & t-value \\
\hline \multicolumn{3}{|c|}{ (Intercept) } & 0.58 & 1.76 \\
\hline \multicolumn{5}{|c|}{ Position in group of siblings (ref. second oldest) } \\
\hline \multirow[t]{3}{*}{ Man } & Eldest brother & $(0.45)$ & -0.47 & -1.54 \\
\hline & Younger brothers & $(0.25)$ & -0.09 & -0.43 \\
\hline & Parents unmarried & $(0.05)$ & 0.48 & 1.13 \\
\hline \multirow[t]{3}{*}{ Woman } & Eldest sister & $(0.39)$ & -0.00 & -0.02 \\
\hline & Younger sisters & $(0.29)$ & -0.04 & 0.19 \\
\hline & Parents unmarried & $(0.05)$ & -0.40 & -0.93 \\
\hline \multicolumn{5}{|c|}{ Age at marriage (ref. man 25-34, woman 23-32) } \\
\hline \multirow[t]{2}{*}{ Man } & Under 25 & $(0.14)$ & 0.23 & 0.91 \\
\hline & Over 34 & $(0.27)$ & -0.16 & -0.83 \\
\hline \multirow{2}{*}{ Woman } & Under 23 & $(0.25)$ & -0.16 & -0.83 \\
\hline & Over 32 & $(0.19)$ & -0.03 & -0.15 \\
\hline \multicolumn{5}{|c|}{ Parents'position at time of marriage (ref. alive) } \\
\hline \multirow[t]{3}{*}{ Man } & Father dead before age 15 & $(0.18)$ & -0.44 & -1.86 \\
\hline & Father dead after age 15 & $(0.29)$ & -0.33 & -1.86 \\
\hline & Mother dead & $(0.29)$ & -0.03 & -0.17 \\
\hline \multirow[t]{3}{*}{ Woman } & Father dead before age 15 & $(0.19)$ & -0.07 & -0.30 \\
\hline & Father dead after age 15 & $(0.21)$ & -0.54 & -2.58 \\
\hline & Mother dead & $(0.26)$ & -0.09 & -0.46 \\
\hline \multicolumn{2}{|c|}{$\begin{array}{l}\text { Social origin of fathers of the couple (ref. man } \\
\text { farmer, woman farm worker) }\end{array}$} & $(0.12)$ & & \\
\hline & Both farmers & $(0.57)$ & 1.13 & 4.76 \\
\hline & Man farm worker, woman farmer & $(0.17)$ & -0.35 & -1.09 \\
\hline & Both farm workers & $(0.10)$ & -0.93 & -2.59 \\
\hline & Farmer and other group & $(0.02)$ & 0.37 & 0.72 \\
\hline & Farm worker and other group & $(0.02)$ & -0.53 & -0.81 \\
\hline & Both other group & $(0.00)$ & -4.49 & -0.94 \\
\hline \multicolumn{2}{|c|}{ Time period (ref. 1830-1870) } & $(0.39)$ & & \\
\hline & $1750-1790$ & $(0.21)$ & -1.00 & -4.42 \\
\hline & $1790-1830$ & $(0.25)$ & -0.53 & -2.59 \\
\hline & $1870-1900$ & $(0.15)$ & -0.42 & -1.74 \\
\hline Eldest so & of a farmer & $(0.31)$ & 1.10 & 3.17 \\
\hline$-2 \log \mathrm{L}$ & & & 2842.8 & \\
\hline $1-($ Resid & ual deviance/Null deviance) & & 0.181 & \\
\hline $\mathrm{N}$ & & & 911 & \\
\hline Events & & & 527 & \\
\hline
\end{tabular}

Bold = significant $\mathrm{p}<0 . \mathrm{I} 0$.

Source: Rendalen database.

number of possible marriage candidates from this group. Controlling for this structural development, our study shows that the boundaries in the marriage market between children of farmers and farm workers prevailed at least until the end of the nineteenth century.

The inhabitants of Rendalen had fairly limited economic possibilities 
during the eighteenth and nineteenth centuries. It was not until the second half of the nineteenth century that emigration to America or migration to the expanding Norwegian cities became an attractive option for a larger segment of young rural men and women. For those that remained in the district, farming and forestry continued to be the dominant industries, and the boundaries between landowners and workers continued in the marriage market. There was little opportunity to break out of the twoclass system by staying in Rendalen. Educational opportunities were limited and a solid economic basis was needed in order to advance socially. For those young people that chose to marry and settle in the home parish there are few traces of a more open society even by the late nineteenth century.

This contributes to and supports the findings of other Norwegian studies dealing with homogamy and social mobility, but it also expands our knowledge to include the second half of the nineteenth century. The limited number of new industries in rural areas made landholding the key determinant of social position, and fear of falling socially virtually compelled the children of farmers to marry among their own class. For farm workers, social boundaries compelled them to marry homogamously too. Sundt concluded that the peasants were more inclined to prioritize the material benefits of marriage than "the mutual tender love of a man or a woman". ${ }^{27}$

This article also tries to discern the parents' role in deciding whom to marry, and the subsequent effect on homogamy. A remnant from preindustrial society was the feeling that parental consent and blessing were needed to ensure a happy marriage. ${ }^{28}$ This study shows that parents exerted influence on the choice of their children's marriage partners. Through the institution of night-courting, young men and women could meet each other and form relationships based on personal affection. But if the father disapproved of the union, the parents could put pressure on their children to end this "courtship". Eldest sons in particular were pressured and encouraged to marry farmers' daughters, as one can see from the way the son's options widened after the death of the father. This is supported by Telste's findings that parents exercised substantial influence on marriage choices until the end of the nineteenth century. ${ }^{29}$

It seems as if, through their influence, fathers were successful in maintaining the social position of their children. The death of the father before the children married had a negative effect on their socio-economic future. Young men and women concerned about their own economic wellbeing therefore took pains to maintain a good relationship with their

27. Sundt, On Marriage in Norway, p. I53.

28. Ørnulf Hodne, Kvinne og mann i norsk folkekultur (Oslo, 2002), p. 99.

29. Telste, "Familien som kjenslefellesskap", p. I37. 
parents. Making their own choice, based on personal attraction, might result in an economically less favourable marriage, and parental influence was therefore not necessarily regarded as running counter to their own interests. 